\title{
Project citizen model to develop student's pro-social awareness
}

\author{
Oom Yomi Romlah ${ }^{1}$, Khaerul Syobar ${ }^{2}$ \\ ${ }^{1}$ Pancasila and Civic Education Study Program, STKIP Pasundan Cimahi, Indonesia \\ ${ }^{2}$ Master of Social Science Education Program, STKIP Pasundan Cimahi, Indonesia
}

\begin{abstract}
Students' learning activities cannot be separated from various factors. The purpose of this study was to determine how project citizen model developed students' pro-social awareness. This study was motivated by diminishing prosocial awareness among students. This study was conducted qualitatively by using case study. The results showed that through project citizen model, students' pro-social awareness could develop. Besides, project citizen mode could help students think critically about social reality. This study recommended to maximize the use of project citizen as a learning model that could develop various potencies of students.
\end{abstract}

Article History:

Submitted : :18-01-2021

Revised : 01-02-2021

Accepted

06-03-2021

Keywords:

project citizen, pro-social awareness, civic education

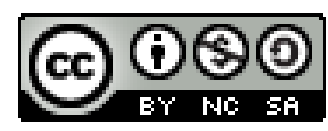

Cite in APA ${ }^{7 \text { th }}$ :

Romlah, O. Y., \& Syobar, K. (2021). Project citizen model to develop student's pro-social awareness. Jurnal Civics: Media Kajian Kewarganegaraan, 18(1), 127-137 https://doi.org/10.21831/jc.v18i1.37982

\section{Introduction}

Students are part of resources that have an important role in the development of a nation. Students have new enthusiasm and hope for change. Brown and Murdolo (2016) confirm that student is a person who has been registered in the university. Hidayah et al. (2020b) emphasize that students are the intellectual generations in higher education. It is not surprising that students have a strategic position in the future of their nation and country.

Considering various potencies and assets inherent in a student, students need to have various competencies that can be beneficial for their future lives at a macro level in a nation's life. Budimansyah and Suryadi (2008) state that students still need a guide to become smart and good citizenship. Matthews (2018) states that students demonstrate complexity of influences and factors that shape success. Therefore, to prepare smart and good citizenship, students' attention needs to be further reflected. The position of student is different according to his purpose. In this case, Borden and Holthaus (2018) describe that in student's position, it needs to be reflected differently according to the goals, interests, and other stakeholders.

The Indonesian is known as a wealthy nation and has a variety of wealth. Indonesia is a sizeable archipelagic country with various cultural artifacts, such as traditional ceremonies, weapons of war, traditional clothing, various arts, and culinary delights. Historical records show that Indonesia has experienced a development process that continues to lead to improvement. However, Pratama (2015) argues that since Indonesia's independence and implementing the trilogy's development concept by using the trickle-down effect theory, it turns out that it has created disparities in economic growth. Hidayah et al., (2020) explain that youth relationships should be highly closed in developing a nation.

Correspondencei: Oom Yomi Romlah, yomikhaerul06@gmail.com, Pancasila and Civic Education Study Program, STKIP Pasundan 
Reasonably, to sustain national development, it is necessary to provide provision for the younger generation to make Indonesia better in the future. Malihah (2015) states that youth who can contribute to development are somewhat Indonesia needs in the future. Indonesia's quality of development can be started by improving education quality. Hidayah et al., (2020a) clarify that one of the improvements in quality is to raise Civic Literacy in Indonesia. In line with this, Edison and Singla (2019) admit that what contributes to the nation's growth is primarily through private investment in the service sector. Therefore, to prepare smart and good citizenship, various Higher Education learning patterns need to be developed.

Granados (2018) states that education and its goals are originally to create a perfect citizen. Besides, Aboutorabi (2015) explains that because every country has its own history, culture, and wills, universities and schools need to assert themselves about what they want. In a broader context, students have a central role in any change. Clycq (2016) strengthens that the education system is an important social and cultural tool. However, in student's learning process at Higher Education, various challenges can lead them to forget the national identity as Indonesian.

Reaching crisis identity, it is necessary to affirm and re-think pro-social attitudes in society which can have positive consequences in the life nations. Anker et al. (2010) state that positive attitudes can be identified across the pro-social domain. The attitude that can positively impact a nation's life is about the development of the socialist ideal of personality and desire to make significant social contributions (Chen, 2019). Then, Black (2021) argues that the best future way to turn back in time is at the state's founding fathers' ideals in the nation's early years. Therefore, the negative phenomenon that appears in pro-social attitudes is a problem that deserves any attention.

The following are various phenomena regarding pro-social issues and the problems. A study on the effect of social empathy on behavior among 126 students at the university in Indonesia with an average of 18-25 years old showed that there was a significant influence between social empathy and social behavior (Umayah et al., 2017). The study results on content mastery with symbolic techniques against pro-social behavior of 25 students at UNNES had a positive effect on students' pro-social behavior (Anggitasari \& Awalya, 2017).

A database search "child", "pro-social development", and "pro-social behavior" results that in the case of infants. Source of pro-social behavior can use stories and be accompanied by good deeds in them (Mareš, 2017). The results showed that a significant relationship was found between prosocial behavior and adolescent self-concept (Deepty \& Geeta, 2015). The study results on the exploration of the antecedents of pro-social behavior among students showed that gender and location were independent factors. In contrast, pro-social behavior as a dependent factor was enormously positive among students. The pro-social culture of students helps students to adapt progressively to society, including universities (Quain et al., 2016).

Furthermore, it appears that pro-social occupies various vital roles in determining a person's attitude tendency. Hidayah and Retnasari (2020) emphasize that Pancasila and Citizenship Education leads to this direction in the discourse of smart and good citizenship. Factually in human relations, especially students, managing and building good relationships is a strength that makes them have a high intellectual and good moral. De Graaf and Paanakker (2014) confirm that validity and transparency are the performance values of others. However, it needs to be pursued and habituated through various learning model schemes in Higher Education.

Budimansyah (2009) argues that project citizen has provided opportunities for students to be able to act as citizen. This study aims to maximize the project citizen model to develop and foster students' pro-social attitudes. This statement is confirmed by Fajri et al. (2018) that the project citizen model can develop students' disposition reflected in the form of responsibility, care, respect for 
opinions, participation, commitment to learning, critical thinking, communication, collaboration, and innovation. Additionally, Medina-Jerez et al. (2010) reinforce that schools worldwide use Project Citizen as a curriculum that promotes the acquisition of academic and life skills, such as citizenship, problem-solving, oral and written communication, and research.

This study purposed to find out how the project citizen model developed students' pro-social awareness. In line with the introduction introduced by Putri et al. (2017), Indonesia is considered a pioneer in implementing open data in Southeast Asia. This study was expected to be a reference base for similar future studies. Kuosa (2011) argues that there have been two paradigms in the evolution of future studies, namely (a) the emergence of a new paradigm and (b) two existing paradigms that have many methodological approaches. Besides, this study's practical benefit was to add insight and knowledge on the project citizen model and pro-social attitudes.

\section{Method}

This study was a qualitative case study. The use of qualitative research was to provide an opportunity for researchers to express research findings. Creswell (2012) argue that qualitative research is a kind of research using that used words as data. Meanwhile, a case study was carried out so that researchers can obtain comprehensive information. In this case, Yin (2006) argue that a case study is used to obtain in-depth information.

This study's subjects were 37 students of the Department of Pancasila and Citizenship Education at STKIP Pasundan, Cimahi. The study was focused on conducted on students in the even semester 2019/2020, namely February to March 2020.

The studied subjects were divided into two large groups and given different themes. The studied subjects practiced the project citizen model in six steps, namely 1 ) identifying the problem; 2) determining the problem; 3) gathering information; 4) creating a portfolio; 5) presenting the portfolio, and 6) reflection. The data were collected through observation, interviews, and documentation. The interview was conducted against eight students who were practicing model project citizens. At the same time, the observation was carried out when the project citizen model occurred. Then, the data analyzed by using the triangulation model.

\section{Result and Discussion}

The implementation of project citizen had provided various learning experiences for students. Munna (2020) explains that current educational practice underlies values, culture, and philosophy, including the concept of education. The interview results with AS regarding the project citizen model showed that the project citizen model could live out a learning atmosphere. "Learning to use project citizen model makes me happy because I can explore learning freely" (US, Feb-2020).

The implementation of project citizens provides a different learning experience for students. Warren et al. (2013) explain that the learning experience is a challenge for educators who want to create interactive media in their classrooms. The project citizen model shows that it can be a single experience for students in their teaching and learning process.

An interview with FK had resulted from the project citizen model enabled us to think critically. In Warren et al. (2013), Dwyer states that critical thinking is an important construct in $21^{\text {st }}$-century learning. In the project citizen model, critical thinking becomes a standard contribution in an enrichment carried out by lecturers. Besides, an interview with VC had shown that the project citizen model could increase students' awareness of daily social situations. Besides, students' daily social situations using the project citizen model are mostly additional activities in their daily lives. Santi (2019) explains that situational experience is formed by a situational framework, where a person can 
see other people and interpret one another. This study also pointed out that the project citizen model also had shortcomings and required a longer learning time.

Figure 1

Students Presenting the Results of a Project Citizen

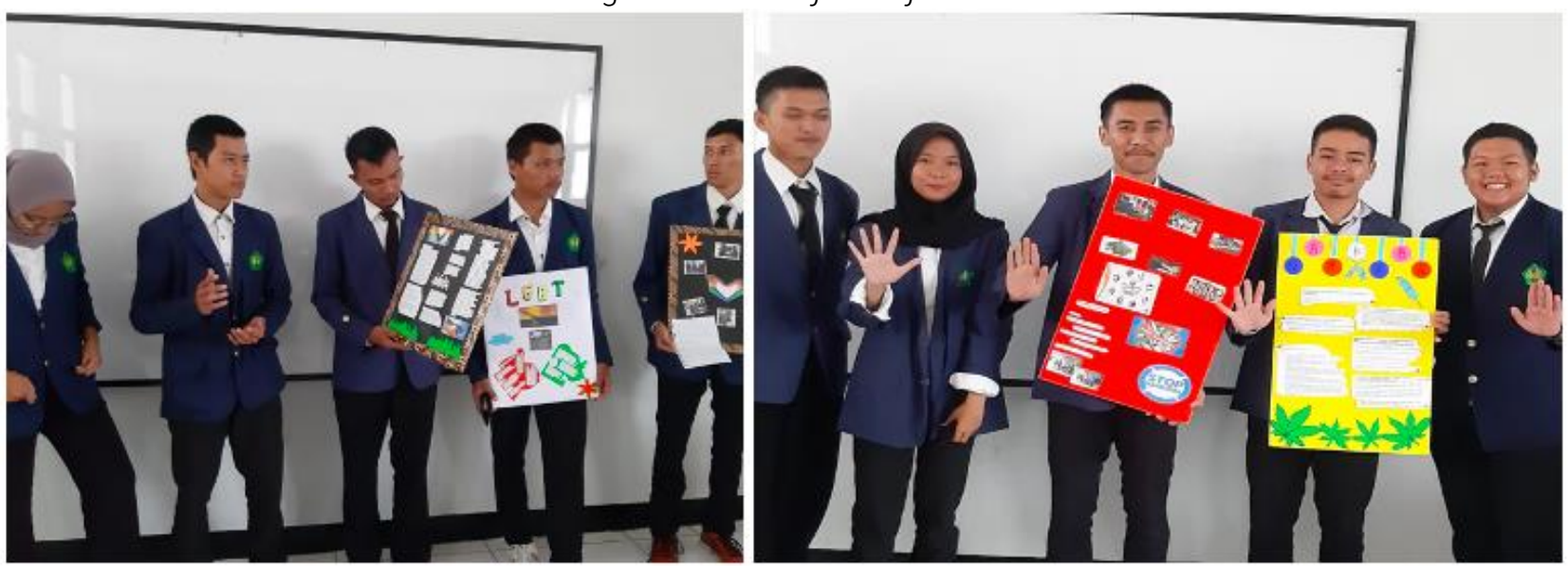

Based on the observation results on the project citizen model, students were quite good at implementing project citizens. This evidence could be seen from various learning activities being organized and coordinated. Bahmani (2016) argue that when students connect to current events, they will present a series of analyses. In regular learning activities and in the practice of the project citizen model, students connect theories to the real world. They also had a smooth presentation. Thus, students can obtain and understand how the learning process occurred.

The observation also showed that the project citizen model was sufficient to provide students with awareness of various phenomena in their real lives. Hewege and Perera (2013) argue that to explore the effectiveness and pedagogical implications, students' real-life phenomena can be a pedagogical implication. Then, these results were confirmed with documentary evidence in the form of students' notes on the problem identification process, and students provided a comprehensive and in-depth problem identification.

Figure 1

Results of a Project Citizen

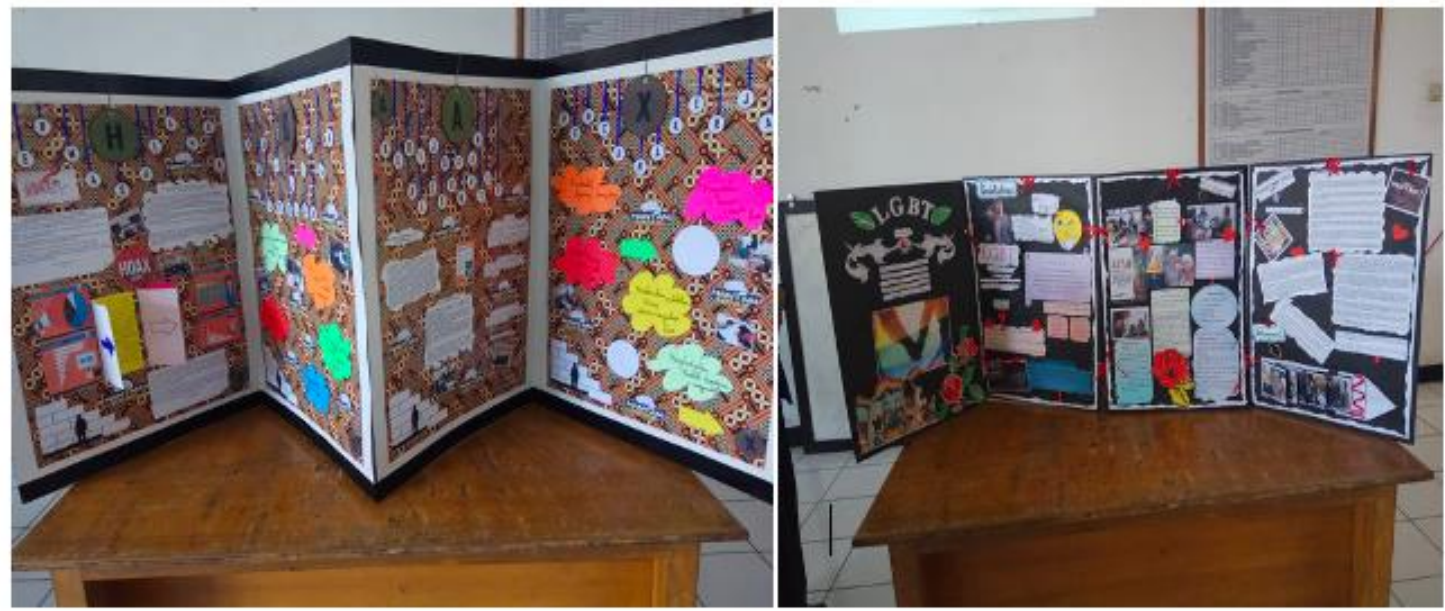

Another idea had shown that students had and applied various pro-social attitudes in implementing project citizen. Hyejin et al. (2021) state that many pro-social attitudes use assertive messages, but ironically assertive messages can cause reactance. As a response to implementing project citizen, students could experience, understand, and shape their pro-social attitudes. Lok 
(2015) explains that the implementation of learning that can experience, understand and shape students' attitudes has become a key role in contributing to the uniqueness of learning to help students critically understand the learning model. An interview with PBD showed that students could learn to work together through project citizens and had mutual tolerance.

Another result showed that the project citizen model provided opportunities for students to think critically and creatively. Wahyudi et al. (2020) stated that the learning scheme's completeness determines students' creative thinking ability. Indeed, this is an exciting thing that students could begin to have and experience the learning process through the project citizen model. Through the project citizen model, learning can provide opportunities for critical and creative thinking. A good and complete scheme in the project citizen model will help students produce critical and creative thinking.

\section{Student's Pro-social Awareness Develops through Project Citizen Model}

The results showed that the project citizen model had provided an unusual learning experience for students. In this context. The project citizen model provides learning experiences to design, implement, or promote solutions to various problems. Tessa et al. (2020) explain that providing learning experiences can be a source for students' information literacy. Therefore, in the practical aspect of project citizens, students tend to be active and cooperated well.

Martini et al. (2018) state that the $21^{\text {st }}$ Century presents various challenges in learning. In this regard, the project citizen model can develop students' pro-social awareness that can answer learning challenges in the $21^{\text {st }}$ Century. The project citizen model also responds to the challenges of $21^{\text {st }}$ century learning in integrating knowledge, skills, and attitudes. Tessa et al. (2019) state that knowledge, skills, and attitudes provide an introductory overview covering all types of lessons. The project citizen model can also provide opportunities to achieve students' information to manage their learning.

Students' pro-social awareness develops through the project citizen model, and it can be identified through some standards, namely: 1) empathy; 2) caring; 3) participation; 4) cooperation; and 5) solution. Hidayah et al. (2020) state that learning can be effective with a specified strategy. In the project citizen model, students' pro-social development with the enrichment of student's intellectual horizons. Botha (2001) explains that the educational process allows flexibility for factors and practices. Through the project citizen model, students can fully develop to achieve learning objectives. Thus, pro-social appears when students can accept and understand what they are doing.

Furthermore, students' pro-social awareness develops through the project citizen model. It signified that their pro-social knowledge increases from their attitudes in implementing the project citizen model. Muhammad et al. (2020) explain that pro-social behavior has the potency to impact pro-social values in improving student attitudes positively. The results showed that the project citizen model provides students with an opportunity to deepen their knowledge, not merely their cognition.

Morgan (2019) argue that someone trying to have a good intention is a person who can properly admit, deserve, and support his mistakes. In line with this study, through the project citizen model, there is a development of attitudes and tendencies resulting from their role in the project citizen model. Thus, a good intention can arise when it occurs; or in another way, there is support from the environment that can support this good intention's growth. It is in line with Suyatno et al. (2019) opinion that factors that appear in the classroom atmosphere are factors that have a significant effect on students' attitudes.

Students' pro-social awareness through the project citizen model had improved along with learning activities through the project citizen model. In this context, Sukma and Evitriana (2019) approve that learning media is a media for training to improve students' abilities. In this case, learning 
media can improve the skills of students. Lei et al. (2020) explain that the significant positive relationship among attitudes positively affects attitudes and intentions. Pro-social awareness through the project citizen model provides a balance in increasing students' pro-social awareness.

The existence of differences in students' pro-social awareness shown through the project citizen model indicates that students sometimes prefer to show their pro-social attitudes because they are in project citizen learning. In line with this, Papanikitas (2017) argues that professionalism is a key component of good general practice, while self-awareness is a key component of professionalism. Wong \& Ng (2021) explained that an education system could only be successful as long as it can develop students in order that they are ready to face the future. Therefore, to achieve pro-social awareness, students experience a reflection process that can bring them closer to prosocial awareness.

\section{Students Think Critically through Project Citizen Model}

This study also showed that the project citizen model had also provided a space for students to think critically. They can present various solutions to their problems. Gonzalez et al.,(2020) explain that there is an innovative evidence-based skills intervention in critical thinking. Therefore, in critical thinking, the project citizen model can help students develop their critical thinking.

The intelligence of citizens accumulates awareness of their rights and obligations as citizens (Hidayah et al., 2020). Through the project citizen model, students seem to have their awareness as citizens when they face a question, "What can I do for this problem?". Lovegreen (2020) explains that critical thinking helps to input project-based learning and maintain the learning component's quality. Through the project citizen model, students' critical thinking is directed to deliberate opinions and concepts.

Endsley (2015) argue that situational awareness has become a widely used construct in the human factors community and has been the focus of research over the past 25 years so that critical thinking for students through the project citizen model has set them in a solution situation because they set in a situation awareness. Lisa et al. (2009) state that awareness is a structural process that integrates critical thinking aspects in students' situations. Through the project citizen model, students are directed not only to think substantively but also on benefits.

Younger generation needs to be equipped with a set of abilities to be a smart nation in the industrial revolution. That encourages the development of students critical thinking will be an effort to manifest smart and good citizenship. Besides, students' critical thinking can reflect a pattern to classify a problem. Zandvakili et al., (2019) argues that critical thinking is what, when, where, how, who, and why questions taken from Aristotle's work "Nicomachean Ethics". Through the project citizen model, students' competency collaboration occurs and can deliver them to critical thinking.

The conceptualization of students' critical thinking through the project citizen model is connected to their reflection based on their problems. Shaw (2014) argue that education has recently begun to condense with critical thinking as a skill in the $21^{\text {st }}$ Century. Howlett et al. (2016) clarify that substantive changes are needed in both curriculum and pedagogical practice to challenge epistemology and dominant discourse about the environment. In line with this, through the project citizen reasoning model, critical thinking can be well trained.

\section{Conclusion}

Referring to the activities being carried out, the project citizen model can develop the potency of students. Related to this, students can develop their pro-social awareness and critical thinking through the project citizen model because it becomes a learning model that can deliver students to the realization of smart and good citizenship. This study implies that the implementation of the 
project citizen model should be maximized as a learning model that can be implemented in other educational institutes. Besides, another possible study on the project citizen model is expected to progress for improvement.

\section{References}

Aboutorabi, R. (2015). Heidegger, education, nation and race. Policy Futures in Education, 13(4), 415423. https://doi.org/10.1177/1478210315571219

Anggitasari, D. W., \& Awalya. (2017). Pengaruh layanan penguasaan konten dengan teknik modeling simbolik terhadap perilaku prososial mahasiswa. Indonesian Journal of Guidance and Counseling, 5(3), 13-18. https://doi.org/10.15294/ijgc.v5i4.13514

Anker, A. E., Feeley, T. H., \& Kim, H. (2010). Examining the attitude-behavior relationship in prosocial donation domains. Journal of Applied Social Psychology, 40(6), 1293-1324. https://doi.org/10.1111/j.1559-1816.2010.00619.x

Bahmani, S. (2016). Improved critical thinking in students using current events journaling. International Journal of Sociology and Social Policy, 36(3/4), 190-202. https://doi.org/10.1108/IJSSP-04-2015-0038

Black, D. W. (2021). Old ideas, not new ones, are the key to education - and democracy. Phi Delta Kappan, 102(5), 38-41. https://doi.org/10.1177/0031721721992564

Borden, V. M. H., \& Holthaus, G. C. (2018). Accounting for student success: Academic and stakeholder perspectives that have shaped the discourse on student success in the United States. International Journal of Chinese Education, 7(1), 150-173. https://doi.org/10.1163/221258681234009

Botha, W. J. J. (2001). Pre-qualification education of registered accountants and auditors in South Africa: Perspectives on whether the education process is normatively justifiable. Meditari Accountancy Research, 9(1), 33-59. https://doi.org/10.1108/10222529200100002

Brown, T., \& Murdolo, Y. (2016). Approaches to study across four year-levels of undergraduate occupational therapy students: Similar or different? British Journal of Occupational Therapy, 79(12), 752-761. https://doi.org/10.1177/0308022616662482

Budimansyah, D. (2009). Inovasi pembelajaran project citizen. SPS-UPI.

Budimansyah, D., \& Suryadi, K. (2008). PKN dan masyarakat multikultural. Program Studi Pendidikan Kewarganegaraan Sekolah Pascasarjana Universitas Pendidikan Indonesia.

Chen, J. (2019). Values reconciliation: Constructing the exemplary ideal personhood through overseas education. Journal of Current Chinese Affairs, 48(1), 29-49. https://doi.org/10.1177/1868102619849761

Clycq, N. (2016). 'We value your food but not your language': Education systems and nation-building processes in Flanders. European Educational Research Journal, 16(4), 407-424. https://doi.org/10.1177/1474904116668885

Creswell, J. W. (2012). Educational research: Planning, conducting, and evaluating quantitative and qualitative research. Pearson.

de Graaf, G., \& Paanakker, H. (2014). Good Governance: Performance Values and Procedural Values in Conflict. The American Review of Public Administration, 45(6), 635-652. https://doi.org/10.1177/0275074014529361 
Deepty, G., \& Geeta, T. (2015). A study of prosocial behaviour and self concept of adolescents. IManager's Journal on Educational Psychology, 8(4), 38-46. https://doi.org/10.26634/jpsy.9.1.3524

Edison, J. C., \& Singla, H. K. (2019). Do public and private project infrastructure expenditure in states contribute to the economic growth of nation? Evidence from India. The Indian Economic Journal, 67(1-2), 9-29. https://doi.org/10.1177/0019466220941663

Endsley, M. R. (2015). Situation awareness misconceptions and misunderstandings. Journal of Cognitive Engineering and Decision Making, 9(1), 4-32. https://doi.org/10.1177/1555343415572631

Fajri, I., Yusuf, R., \& Ruslan. (2018). Project citizen learning model in developing civic disposition of high school students through the subject of Pancasila education citizenship. Proceedings of the International Conference on the Roles of Parents in Shaping Children's Characters (ICECED), 393-404.

Gonzalez, H. C., Hsiao, E.-L., Dees, D. C., Noviello, S. R., \& Gerber, B. L. (2020). Promoting critical thinking through an evidence-based skills fair intervention. Journal of Research in Innovative Teaching \& Learning, ahead-of-print(ahead-of-print). https://doi.org/10.1108/jrit-08-20200041

Granados, J. (2018). The challenges of higher education in the 21st century. http://www.guninetwork.org/articles/challenges-higher-education-21st-century

Hewege, C. R., \& Perera, L. C. R. (2013). Pedagogical significance of wikis: Towards gaining effective learning outcomes. Journal of International Education in Business, 6(1), 51-70. https://doi.org/10.1108/18363261311314953

Hidayah, Y., Halimah, L., Trihastuti, M., Dewie, D. A., Feriandi, Y. A., \& Dianasari, D. (2020). How did prospective elementary school teacher learn citizenship education during the pandemic covid19 in Indonesia? IJERI: International Journal of Educational Research and Innovation, 15(15), 373-387. https://doi.org/10.46661/ijeri.5329

Hidayah, Y., \& Retnasari, L. (2020). Reorientasi Pendidikan Pancasila dan Kewarganegaraan pada sekolah dasar dalam wacana kewarganegaraan smart and good citizen. Jurnal Citizenship: Media Publikasi Pendidikan Pancasila Dan Kewarganegaraan, 2(1), 27. https://doi.org/10.12928/citizenship.v2i1.12938

Hidayah, Y., Sapriya, Darmawan, C., \& Malihah, E. (2020a). Penggalangan civic literacy melalui organisasi kemahasiswaan dan pandangan mengenai tantangan demokrasi di Indonesia. Jurnal Pemikiran Sosiologi, 7(1), 31-46. https://doi.org/10.22146/jps.v7i1.57674

Hidayah, Y., Sapriya, Dermawan, C., \& Malihah, E. (2020). Learning service through college student organization as a political awareness on higher education. Journal of Physics: Conference Series, 1446, 12052. https://doi.org/10.1088/1742-6596/1446/1/012052

Hidayah, Y., Sapriya, S., Darmawan, C., \& Malihah, E. (2020b). Student organizations as voluntary groups in tertiary education: Enculturation and balancing political engagement for Indonesian generation Z. The International Journal of Civic, Political, and Community Studies, 18(1), 1-12. https://doi.org/10.18848/2327-0047/CGP/v18i01/1-12

Howlett, C., Ferreira, J.-A., \& Blomfield, J. (2016). Teaching sustainable development in higher education. International Journal of Sustainability in Higher Education, 17(3), 305-321. https://doi.org/10.1108/IJSHE-07-2014-0102 
Hyejin, B., Dongwon, C., Sukki, Y., Hyun, B. T., \& Yeonshin, K. (2021). Message assertiveness and price discount in prosocial advertising: differences between Americans and Koreans. In European Journal of Marketing: Vol. ahead-of-p (Issue ahead-of-print). https://doi.org/10.1108/EJM-102019-0791

Kuosa, T. (2011). Evolution of futures studies. Futures, 43(3), 327-336. https://doi.org/10.1016/j.futures.2010.04.001

Lei, W., Weng, W. P. P., \& Elangkovan, N. A. (2020). Antecedents of green purchase behaviour: an examination of altruism and environmental knowledge. International Journal of Culture, Tourism and Hospitality Research, 14(1), 63-82. https://doi.org/10.1108/IJCTHR-02-2019-0034

Lisa, W., Beate, B., \& Laura, K. L. (2009). Assessing quality of critical thought in online discussion. Campus-Wide Information Systems, 26(3), 168-177. https://doi.org/10.1108/10650740910967357

Lok, C. K. (2015). Adoption of smart card-based e-payment system for retailing in Hong Kong using an extended technology acceptance model. In E-services Adoption: Processes by Firms in Developing Nations (Vol. 23B, pp. 255-466). Emerald Group Publishing Limited. https://doi.org/10.1108/S1069-09642015000023B003

Lovegreen, V. (2020). Critical Thinking Pedagogy and Quality Assurance in the United States. In H. Flavian (Ed.), From Pedagogy to Quality Assurance in Education: An International Perspective (pp. 13-28). Emerald Publishing Limited. https://doi.org/10.1108/978-1-83867-106820201004

Malihah, E. (2015). An ideal Indonesian in an increasingly competitive world: Personal character and values required to realise a projected 2045 'Golden Indonesia.' Citizenship, Social and Economics Education, 14(2), 148-156. https://doi.org/10.1177/2047173415597143

Mareš, J. (2017). Prosocial behavior education in children. Acta Technologica Dubnicae, 7(2), 7-16. https://doi.org/10.1515/atd-2017-0009

Martini, E., Trihastuti, M., \& Candra, A. A. (2018). Understanding of human rights through civic education in the 21st century. Proceedings of the Annual Civic Education Conference (ACEC 2018), 497-500. https://doi.org/10.2991/acec-18.2018.114

Matthews, K. E. (2018). Engaging students as participants and partners: An argument for partnership with students in higher education research on student success. International Journal of Chinese Education, 7(1), 42-64. https://doi.org/10.1163/22125868-1234008

Medina-Jerez, W., Bryant, C., \& Green, C. (2010). Project citizen: Students practice democratic principles while conducting community projects. Science Scope, 33(7), 71-75. https://www.researchgate.net/publication/234675754_Project_Citizen_Students_Practice_D emocratic_Principles_While_Conducting_Community_Projects

Morgan, J. (2019). Guilt, self-awareness, and the good will in Kierkegaard's confessional discourses. Studies in Christian Ethics, 33(3), 352-370. https://doi.org/10.1177/0953946818822277

Muhammad, T., Hillman, W., Triani, A., \& Sutopo, P. R. P. (2020). Predicting pro-environmental behaviours: the role of environmental values, attitudes and knowledge. Management of Environmental Quality: An International Journal, 32(2), 328-343. https://doi.org/10.1108/MEQ-12-2019-0264

Munna, A. S. (2020). International students' learning experience on global curriculum. Journal of Education, 00(0), 1-12. https://doi.org/10.1177/0022057420972063 
Papanikitas, A. (2017). Self-awareness and professionalism. InnovAiT: Education and Inspiration for General Practice, 10(8), 452-457. https://doi.org/10.1177/1755738017710962

Pratama, Y. C. (2015). Analisis faktor-faktor yang mempengaruhi kemiskinan di Indonesia. ESENSI, 4(2), 210-223. https://doi.org/10.15408/ess.v4i2.1966

Putri, D. A., Karlina-CH, M., Tanaya, J., \& Canares, M. (2017). How do citizens benefit from a smart city? A case study of Jakarta, Indonesia. http://webfoundation.org/docs/2017/08/RP-Citizensand-smart-city-Jakarta-082017.pdf

Quain, S., Yidana, X. D., \& Ambotumah, B. B. (2016). Pro-social behavior amongst students of tertiary institutions: An explorative and a quantitative approach. Journal of Education and Practice, 7(9), 26-33. https://www.iiste.org/Journals/index.php/JEP/article/view/29617/30410

Santi, F. (2019). Situating frames and institutional logics: The social situation as a key institutional microfoundation. In P. Haack, J. Sieweke, \& L. Wessel (Eds.), Microfoundations of Institutions (Vol. 65B, pp. 193-209). Emerald Publishing Limited. https://doi.org/10.1108/S0733558X2019000065B015

Shaw, R. D. (2014). How critical Is critical thinking? Music Educators Journal, 101(2), 65-70. https://doi.org/10.1177/0027432114544376

Sukma, H. H., \& Evitriana, N. (2019). Pengembangan media audio visual sebagai media pembelajaran menyimak komprehensif berbasis budaya nusantara untuk Kelas III sekolah dasar. Prosiding Seminar Nasional Pagelaran Pendidikan Dasar Nasional (PPDN) 2019, 1(1), 408-416. http://seminar.uad.ac.id/index.php/ppdn/article/view/1424

Suyatno, S., Mardati, A., Wantini, W., Pambudi, D. I., \& Amurdawati, G. (2019). The impact of teacher values, classroom atmosphere, and student-teacher relationship towards student attitude during learning process. International Journal of Learning, Teaching and Educational Research, 18(8), 54-74. https://doi.org/10.26803/ijlter.18.8.4

Tessa, W., Joanna, M. K., Caffrey, G. C., Anthony, A., Cristina, S., Dana, O., Maggie, C., George, M., Amalia, C., Aric, H., \& Wendolyn, V. (2020). Library instruction and information literacy 2019. Reference Services Review, 48(4), 601-682. https://doi.org/10.1108/RSR-08-2020-0057

Umayah, A. N., Ariyanto, A., \& Yustisia, W. (2017). Pengaruh empati emosional terhadap perilaku prososial yang dimoderasi oleh jenis kelamin pada mahasiswa. Jurnal Psikologi Sosial, 15(2), 72-83. https://doi.org/10.7454/jps.2017.7

Wahyudi, W., Waluya, S. B., Suyitno, H., \& Isnarto, I. (2020). Schemata and creative thinking ability in cool-critical-creative-meaningful (3CM) learning. International Journal of Sustainability in Higher Education, 22(1), 1-28. https://doi.org/10.1108/IJSHE-06-2019-0198

Warren, S. J., Wakefield, J. S., \& Mills, L. A. (2013). Learning and teaching as communicative actions: Transmedia storytelling. In L. A. Wankel \& P. Blessinger (Eds.), Increasing Student Engagement and Retention using Multimedia Technologies: Video Annotation, Multimedia Applications, Videoconferencing and Transmedia Storytelling: Vol. 6 Part F (pp. 67-94). Emerald Group Publishing Limited. https://doi.org/10.1108/S2044-9968(2013)000006F006

Withorn, T., Gardner, C. C., Messer Kimmitt, J., Eslami, J., Andora, A., Clarke, M., Patch, N., Salinas Guajardo, K., \& Lunsford, S. (2019). Library instruction and information literacy 2018. Reference Services Review, 47(4), 363-447. https://doi.org/10.1108/RSR-08-2019-0047 
Wong, C. P., \& Ng, D. (2021). The roles of school leaders in developing future-ready learners: The case of Singapore. International Journal of Educational Management, 35(1), 249-269. https://doi.org/10.1108/IJEM-06-2020-0283

Yin, R. K. (2006). Case study methods. In Handbook of complementary methods in education research. (pp. 111-122). Lawrence Erlbaum Associates Publishers.

Zandvakili, E., Washington, E., Gordon, E. W., Wells, C., \& Mangaliso, M. (2019). Teaching patterns of critical thinking: The 3ca model-concept maps, critical thinking, collaboration, and assessment. SAGE Open, 9(4), 215824401988514. https://doi.org/10.1177/2158244019885142 